\title{
ADULT EDUCATION IN TRANSITION
}

\author{
A STUDY OF \\ INSTITUTIONAL INSECURITY
}

\author{
$\mathbf{B Y}$ \\ BURTON R. CLARK
}

UNIVERSITY OF CALIFORNIA PRESS

BERKELEY AND LOS ANGELES

1968 


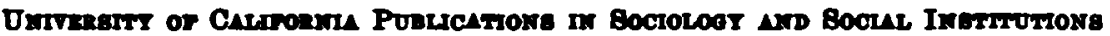

THIDD PANTING, 1968

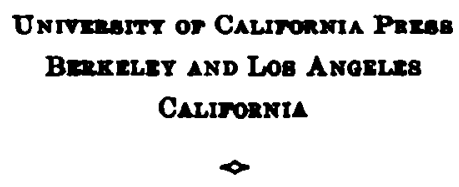

Caymaidor Univereity Press

Loxpor, Exolasd 